\title{
New Radiocarbon Dates from Ancestral Caddo Sites in Cherokee, Fannin, Hopkins, Nacogdoches, and Wood Counties, Texas
}

Timothy K. Perttula

Heritage Research Center, Stephen F. Austin State University

Follow this and additional works at: https://scholarworks.sfasu.edu/ita

Part of the American Material Culture Commons, Archaeological Anthropology Commons, Environmental Studies Commons, Other American Studies Commons, Other Arts and Humanities Commons, Other History of Art, Architecture, and Archaeology Commons, and the United States History Commons

Tell us how this article helped you.

This Article is brought to you for free and open access by the Center for Regional Heritage Research at SFA ScholarWorks. It has been accepted for inclusion in Index of Texas Archaeology: Open Access Gray Literature from the Lone Star State by an authorized editor of SFA ScholarWorks. For more information, please contact cdsscholarworks@sfasu.edu. 
New Radiocarbon Dates from Ancestral Caddo Sites in Cherokee, Fannin, Hopkins, Nacogdoches, and Wood Counties, Texas

\section{Creative Commons License}

\section{(c) (1) (8)}

This work is licensed under a Creative Commons Attribution-NonCommercial 4.0 International License 


\title{
New Radiocarbon Dates from Ancestral Caddo Sites in Cherokee, Fannin, Hopkins, Nacogdoches, and Wood Counties, Texas
}

\author{
Timothy K. Perttula
}

\section{Introduction}

In order to continue to expand the utility of the East Texas Radiocarbon Database to better understand the age of archaeological components at sites, as well as temporal trends in settlement by Native Americans in East Texas (cf. Selden 2012; Selden and Perttula 2013a, 2013b), archaeologists need to seek out samples wherever such samples can be obtained. This includes organic remains (i.e., plant and animal remains) from intact archaeological deposits as well as organic remains preserved in well-maintained curated collections. This article presents the results of AMS dating of plant remains or animal bones at five different ancestral Caddo sites in East Texas.

\section{Radiocarbon Dates from Sites}

The radiocarbon analyses discussed in this article were done by DirectAMS of Seattle, Washington. Four of the sites have only a single AMS radiocarbon date, while five radiocarbon dates have been obtained from one site. The radiocarbon ages obtained on these samples have been calibrated to 2 sigma using IntCal13 (Reimer et al. 2013).

\section{Bowles Creek Site (41CE475)}

The Bowles Creek site is on a low alluvial rise in the Bowles Creek floodplain (Perttula et al. 2016a); Bowles Creek is a southward-flowing tributary of the Neches River. The one radiocarbon date was obtained on a piece of animal bone from Unit 3, 40-50 cm bs. The character of the recovered ceramics from the site suggest the ancestral Caddo occupation primarily dates after ca. A.D. 1650, in the Allen phase, although the occurrence of both Poynor Engraved and Patton Engraved sherds in the assemblage (Perttula et al. 2016a:Table 15) may indicate that the site was also used by Caddo peoples sometime before A.D. 1650.

The radiocarbon age of the one AMS sample from the Bowles Creek site is $410 \pm 24$ years B.P. (DAMS 11799), or A.D. $1540 \pm 24$. The 2 sigma calibration (95 percent probability) of this radiocarbon age is A.D. $1525 \pm 84$. This result suggests that there are Frankston phase (ca. A.D. 1400-1650) archaeological deposits preserved at the site.

\section{North Ridge Site (41FN178)}

The North Ridge site is on an alluvial terrace landform in the Bois d'Arc Creek valley (Perttula et al. 2016b). Bois d'Arc Creek is a northward-flowing tributary to the Red River, and its confluence with the Red River is adjacent to the ancestral Caddo Sanders site (41LR2), an important mound center occupied primarily between ca. A.D. 1100-1300 in the Early and Middle Caddo periods. Ceramic sherds and arrow points in a private collection from the site, as well as the recovery of a tool punctated body sherd in recent shovel testing, suggests that the site was occupied prior to ca. A.D. 1200. 
During shovel test investigations in July 2015, charred hickory (Carya sp.) nutshell fragments were recovered between 0-24 cm bs in sandy loam A-horizon deposits at the site. These charred nutshells were submitted to Direct-AMS for radiocarbon dating. The radiocarbon age of these hickory nutshells from the North Ridge site is $952 \pm 25$ B.P., or A.D. $998 \pm 25$ (D-AMS 11793). The 2 sigma calibration of this radiocarbon age is A.D. $1090 \pm 67$, dating to the Early Caddo period.

\section{Culpepper Site (41HP1)}

The Culpepper site is one of a number of known Titus phase (dating from ca. A.D. 1430-1680) Caddo sites along Stouts Creek in Hopkins County, Texas; Stouts Creek is a small northward-flowing stream in the White Oak Creek basin of the larger Sulphur River drainage.. These sites have habitation archaeological deposits as well as family cemeteries (Perttula 2016). In 1931, University of Texas archaeologists excavated eight ancestral Caddo burial features at the site, and recovered a number of ceramic vessels placed in the burials by the Caddo as funerary offerings. These vessels are curated by the Texas Archeological Research Laboratory at The University of Texas at Austin (TARL).

Vessel 4 in Burial 1 at the Culpepper site is a grog-tempered La Rue Neck Banded jar (Perttula 2016). It had extensive organic residue on the interior rim and body, and a sample of this residue was submitted for radiocarbon dating. The radiocarbon age obtained on this organic residue is $361 \pm 24$ years B.P. (D-AMS 11791), or A.D. $1589 \pm 24$. The 2 sigma calibration of the radiocarbon age is A.D. $1542 \pm$ 90, indicating that the vessel was placed in a Titus phase burial feature at the Culpepper site.

\section{Washington Square Mound Site (41NA49)}

The Washington Square Mound site (41NA49) is a Caddo multiple mound center located on an upland interfluve between Banita Creek on the west and La Nana Creek on the east, within the city limits of Nacogdoches, Texas (Corbin and Hart 1998; Perttula 2009); both streams are southern-flowing tributaries of the Angelina River. The site appears to have primarily been occupied by ancestors of the modern-day Caddo Indian peoples between ca. A.D. 1250-1425. During this occupation, the Caddo erected at least three mounds, the University Mound or Mounds 1/2, Mound 3, and Mound 4 or the Reavely-House Mound. Mound 1/2 was constructed by the Caddo over an important building, as was apparently also the case for Mound 3, the largest of the known mounds at Washington Square, while Mound 4 was a Caddo burial mound.

Extensive excavations reported by Corbin and Hart (1998) documented a circular structure under Mound 1/2, an assortment of pits and postholes in non-mound contexts (the source of the samples discussed below), and several large burial pits in a mortuary mound (the Reavely-House Mound). No clear evidence for on-site permanent Caddo habitation was identified at Washington Square, although there were a number of large sherd-filled pits (representing many vessels) encountered in one area between Mound $1 / 2$ and the mortuary mound. These may represent deposits from public feasting activities led by the Caddo elite that used the Washington Square mound site as a ceremonial center in the 13th and 14th centuries.

The five new radiocarbon dates from the Washington Square Mound site are from non-mound features (Table 1), pits (Feature 115, see Corbin and Hart 1998:63-64 and Figure 21), charcoal-filled pits (Features 9, 81, and 86), or a concentration of corn cobs (Feature 36). The dates from Features 9 and 115 are on charred hickory nutshells, while the dates on Features 36,81, and 86 are on charred corn fragments. 
Table 1. New radiocarbon samples from the Washington Square Mound site (41NA49).

\begin{tabular}{llll}
\hline Feature No. & D-AMS No. & Radiocarbon age (B.P.) & $\begin{array}{l}\text { Calibrated age, } 2 \text { sigma } \\
\text { (A.D.)* }\end{array}$ \\
\hline 9 & 11794 & $584 \pm 28$ & A.D. $1358 \pm 57$ \\
36 & 11798 & $540 \pm 25$ & A.D. $1412 \pm 18$ \\
81 & 11797 & $511 \pm 27$ & A.D. $1419 \pm 17$ \\
86 & 11796 & $522 \pm 27$ & A.D. $1418 \pm 19$ \\
115 & 11795 & $716 \pm 31$ & A.D. $1279 \pm 17$ \\
\hline
\end{tabular}

*IntCal13, from Reimer et al. 2013

The 2 sigma calibrated ages of the five radiocarbon dates fall into three groups: (1) the earliest calibrated age range is A.D. $1279 \pm 17$ from Feature 115; (2) the Feature 9 calibrated age of A.D. $1358 \pm$ 57; and (3) the three dates on charred corn from Features 36, 81, and 86 that range from as early as A.D. 1394 to as late as A.D. 1437 (see Table 1). These dates as a group fall in the Middle Caddo period and the earliest years of the Late Caddo period, if the Late Caddo period is considered to begin at ca. A.D. 1400 (Perttula 2012:Table 1-1).

Twelve earlier radiocarbon dates have been obtained on plant remains (i.e., wood charcoal, pine cone fragments, nutshell, and charred corn) from features at the Washington Square Mound site (Corbin and Hart 1998:Table 4). However, these dates are not particularly useful in reasonably establishing the precise age of the Caddo occupation(s) at the site because they have large standard deviations ranging between 50 and 260 years. One of the 12 dates was on charred corn from Feature 9, and the radiocarbon age was determined to be $630 \pm 60$ years B.P.; this date on corn overlaps with the date recently obtained on charred nutshells from the same feature (see Table 1). Corbin and Hart (1998:Table 4) pooled and calibrated seven of the 12 radiocarbon dates (even though one of the radiocarbon dates had a 200 year standard deviation) from the Washington Square Mound site and obtained a pooled radiocarbon age of $720 \pm 28$ years B.P. Calibrating the pooled radiocarbon age using IntCal13 produces a calibrated age range of A.D. 1261-1293. This pooled sample of radiocarbon dates also falls squarely in the Middle Caddo period, and temporally aligns with the A.D. 1271-1287 calibrated age range obtained on charred nutshells from Feature 115.

\section{J. H. Reese Site (41WD2)}

The J. H. Reese site (41WD2) is an ancestral Caddo habitation area and small cemetery dating to the Late Caddo period Titus phase in the Little Dry Creek valley in the upper Sabine River basin (Perttula and Walters 2016). University of Texas archaeologists excavated three burials at the site in 1930; each burial had associated ceramic vessel funerary offerings.

Vessel 12 in Burial 1 at the site is a rimpeaked La Rue Neck banded jar (Figure 1) with thick organic residue on the exterior rim and body. A sample of this organic residue was collected as a radiocarbon sample.

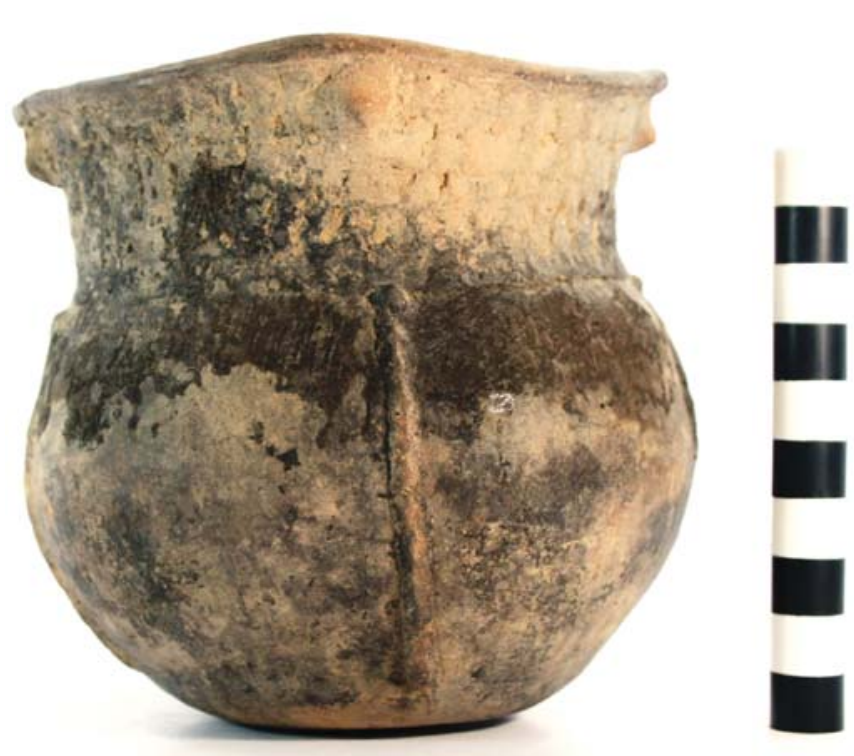

Figure 1. La Rue Neck Banded jar (Vessel 12) from the J. H. Reese site (41WD2). 
The radiocarbon age of the organic residue on the La Rue Neck Banded jar is $432 \pm 27$ years B.P. (DAMS 11792), or A.D. $1518 \pm 27$. The 2 sigma calibration of this radiocarbon age from the La Rue Neck Banded jar is A.D. $1453 \pm 20$, indicating that the vessel was placed in an early Titus phase burial feature at the J. H. Reese site.

\section{Summary and Conclusions}

Nine new radiocarbon dates have been obtained from ancestral Caddo sites in Cherokee (Neches River basin), Fannin (Red River basin), Hopkins (Sulphur River basin), Nacogdoches (Angelina River basin), and Wood (Sabine River basin) counties in East Texas. The 2 sigma calibrated age ranges of these radiocarbon samples are indicative of Early (A.D. 1022-1157), Middle (A.D. 1261-1437, but in three temporally distinct groupings), and Late (A.D. 1432-1473, A.D. 1441-1609, and A.D. 1453-1632) Caddo occupations at these habitation and cemetery sites. Hopefully more radiocarbon samples can be obtained and analyzed from these sites, as well as more radiocarbon samples from likely contemporaneous ancestral Caddo components at other sites in the region.

\section{Acknowledgments}

Thanks to Kevin Stingley for providing the deer bone from the Bowles Creek site for radiocarbon dating. George Avery and Leslie Bush were of considerable assistance in either locating the paleobotanical remains from the Washington Square Mound site or sorting the remains to help select suitable samples for AMS dating. Thanks also to the folks at TARL for facilitating the documentation of the ceramic vessels from the Culpepper and J. H. Reese sites.

\section{References Cited}

Corbin, J. E. and J. P. Hart

1998 The Washington Square Mound Site: A Middle Caddo Mound Complex in South Central East Texas. Bulletin of the Texas Archeological Society 69:47-78.

Perttula, T. K.

2009 Caddo Ceramic and Lithic Artifacts from the Washington Square Mound Site (41NA49) in Nacogdoches County, Texas: 1985 Texas Archeological Field School Investigations. Bulletin of the Texas Archeological Society 80:145-193.

2012 The Archaeology of the Caddo in Southwest Arkansas, Northwest Louisiana, Eastern Oklahoma, and East Texas: An Introduction to the Volume. In The Archaeology of the Caddo, edited by T. K. Perttula and C. P. Walker, pp. 1-25. University of Nebraska Press, Lincoln.

2016 Documentation of the Caddo Ceramic Vessels from the Culpepper Site (4HP1) in Hopkins County in the Upper Sulphur River Basin in East Texas. Journal of Northeast Texas Archaeology 65:53-98.

Perttula, T. K. and M. Walters

2016 Ceramic Vessels from Caddo Sites in Wood County, Texas. Journal of Northeast Texas Archaeology 63:75-131.

Perttula, T. K., K. Stingley, and M. Walters

2016a Historic Caddo Archaeological Sites in Cherokee County, Texas. Journal of Northeast Texas Archaeology 65:1-24.

Perttula, T. K., M. Walters, R. J. Nelson, and G. W. Cheatwood

2016b Archaeological Survey Investigations of Private Land within the boundaries of the proposed Lower Bois d'Arc Creek Reservoir Project, Fannin County, Texas. Journal of Northeast Texas Archaeology 66:21-30. 
Reimer, P. J., E. Bard, A. Bayliss, J. W. Beck, P. G. Blackwell, C. Bronk Ramsey, C. E. Buck, H. Cheng, R. L. Edwards, M. Friedrich, P. M. Grootes, T. P. Guilderson, H. Haflidason, I. Hajdas, C. Hatte, T. J. Heaton, D. L. Hoffman, A. G. Hogg, K. A. Hughen, K. F. Kaiser, B. Kromer, S. W. Manning, M. Niu, R. W. Reimer, D. A. Richards, E. M. Scitt, J. R. Southon, R. A. Staff, C. S. M. Turney, and J. van der Plicht

2013 IntCal13 and Marine13 Radiocarbon Age Calibration Curves 0-50,000 Years Cal BP. Radiocarbon 55(4):1869-1887.

Selden, R. Z. Jr.

2012 Modeling Regional Radiocarbon Trends: A Case Study from the East Texas Woodland Period. Radiocarbon 54(2):239-265.

Selden, R. Z., Jr. and T. K. Perttula

2013a Radiocarbon Trends and the East Texas Caddo Tradition (ca. A.D. 800-1680). Southeastern Archaeology 32(1):85-96.

2013b Temporal Dynamics of East Texas Caddo Sites with 10 or More Radiocarbon Dates. Journal of Northeast Texas Archaeology 41:81-99. 